\title{
Rəqəmli təsvirlərin watershed üsulu ilə seqmentləşdirilməsi
}

\author{
Ababil Nağıyeva ${ }^{1}$, Sakit Verdiyev ${ }^{2}$ \\ Azərbaycan Texnologiya Universiteti, Gəncə, Azərbaycan \\ ${ }^{1}$ nagiyevaababilegmail.com, ${ }^{2}$ info_teleinbox.ru
}

\begin{abstract}
Xülaso-Seqmentləşmə təsvirlərin işlənilməsində rəqəmli təsvirin bir neçə seqmentə bölünməsidir. Bu məqalədə rəngli təsvirlərin kompüter tərəfindən tanınması və yaxud rəqəmli təsvirin konteyner kimi istifadəsinin effektivliyini artırmaq məqsədi ilə emal üsullarından biri olan seqmentloşdirilmonin müxtəlif texnikaları barədə məlumat verilir, konkret səkildə suayırıcı (watershed) üsulunun xüsusiyyətləri vo matlabda işləmə metodikası verilib. Nümunə kimi rəngli, rəqəmsal təsvirin Qradiyent üsulu ilə seqmentloşdiriməsi verilib. Nəticə kimi göstərilib ki, həddən artıq seqmentloşdirilmə effektinin mövcudluğu bu üsulun çatışmazlıqlarına aiddir və yeni, daha kamil üsulun işlənilməsinə ehtiyac vardır.
\end{abstract}

Açar sözlər: rəqəomli təsvir, seqmentləşdirilmə, watershed, qradiyent, piksel koordinatları.

\section{GİRİŞ}

Yüksək texnologiyaların inkişaf edərək gündəlik həyatımızın hər bir sahəsinə daxil olduğu dövrdə rəqəmli təsvirlərdən də geniş istifadə olunur. Bu isə öz növbəsində informasiyanın istər korporativ, istər hərbi səviyyədə təhlükəsiz, qorunmuş halda dövriyyəsinin təmin edilməsini tələb edir və təsvir verilənlərinin icazəsi olmayan istifadəçilərdən mühafizə olma üsullarının işlənilməsini aktual edir. $\mathrm{Bu}$ üsullar o dərəcədə etibarlı olmalıdır ki, ötürülməli olan orijinal verilənlər istənilən haker, həmçinin server adminstratoru üçün əlçatan olmasın [1].

Təsvirlərin analizi zamanı onların piksellərinin müəyyən əlamətlərinə görə qruplaşdırılmasıdır. Ayrı ayrı qruplar isə seqment adlanır. İki növ qruplaşma (seqmentləşdirmə) məlumdu: binar təsvirlər üçün parlaqlıqlarına görə və rəngli təsvirlərdə rəng koordinatlarına görə. Olamətlər məkanında hər bir pikselin koordinatlarını (x,y) və RGB komponentlərini seçmək olar. Seqmentlər bir birindən parlaqlıq, rəng, tekstura, forma və digər əlamətlər ilə fərqlənirlər. Seqmentləşdirilmənin məqsədi təsvirin sadələşməsi. Bu ona görə edilir ki, təsvir emal və analiz edilə bilsin. Seqmentlərin düzgün seçilməsi təsvirin tanınmasının keyfiyyətinə təsir edir [2].

\section{SEQMENTLOȘDIRMӘ}

Rəqəmli təsvirlərin seqmentləşdirilməsi onların eyni sahəyə məxsus piksellərini qruplaşdıraraq, təsvirdə olan müxtəlif obyektləri bir birindən seçmək və bunula yanaş1 təsvirdə olan müxtəlif obyektlərin təsvirin arxa fonundan seçilməsi deməkdir. Daha aydın desək, rəqəmli təsvirin seqmentləşdirilməsi, təsvirin kompüter tərəfindən tanınması və üzərində emal aparılacaq sahələrin müəyyənləşdirilməsidir.
Eyni obyektə məxsus piksellərin hər biri rəngin intensivliyi kimi bəzi xüsusiyyətlərə aiddir. Bitişik bölgələr xarakteristikalarına görə bir birindən əhəmiyyətli dərəcədə fərqlənə bilir. Seqmentləşdirmənin praktiki istifadəsinə aşağıdakıları aid etmək olar.

- Insanın biometrik xüsusiyyətlərinin müəyyən edilməsi:

- barmaq izinin tanınması;

- təsvirdə üzün tanınması;

- gözün qişasının tanınması;

- Təsvirin steqoanalizi;

- Tibbi Görüntülərin emalı və s. [3]

Təsvirlərin seqmentləşməsinin aparılması üçün təsvirdə olan piksellərin $\mathbf{x}$ və $\mathbf{y}$ oxları üzrə koordinatları müəyyən edilir. Daha sonra əldə olunan qiymətlərdən istifadə edərək Qradiyent, Laplas və s. kimi riyazi əməliyyatların köməyi ilə təsvirlər seqmentləşdirilir.

Təsvirlərin seqmentləşdirilməsi üçün bir çox alqoritimlər mövcuddur. Bunlara k-ortalama, Suayırıcı (Watershed) alqoritimlərini və s. misal göstərə bilərik.

Qeyd etmək lazımdır ki, bir təsvir üçün istifadə olunan seqmentləşdirmə üsulu digər bir təsvir üçün yararlı olmaya da bilər. Yəni elə bir universal seqmentləşdirmə üsulu mövcud deyildir ki, o bütün təsvirlər üçün uğurlu nəticə versin.

$\mathrm{Bu}$ məqalədə seqmentləşdirmədə geniş istifadə olunan Məsafə çevrilməsi və Qradiyent üsulları nəzərdən keçirilərək, mövcud ədəbiyyatdan istifadə etməklə müqayisəli təhlil edilir. Misal kimi isə Qradiyent üsulu nümunəsində işləmə metodikasina baxilır.

Məsafə çevrilməsi üsulunun seqmentləşdirilməsi piksellərin Watershed xəttinə kimi olan məsafənin ölçülməsinə əsaslanır. Məsafə çevrilməsi təsvirində birinci şəkildəki xətlər Watershed xətləridir, ikinci şəkildə isə seqmentləşdirilmə nəticəsində tədqiq edilməli olan ayrı-ayrı obyektlərin konturlarıdır. Digər çox effektiv işləyən yanaşma Qradiyentlər vasitəsilə Watershed üzrə seqmentləşdirilmədir (Şəkil 3,4). 


\section{“Informasiya tohlükasizliyinin aktual multidissiplinar elmi-praktiki problemlori” \\ IV respublika konfransl, 14 dekabr 2018-ci il}
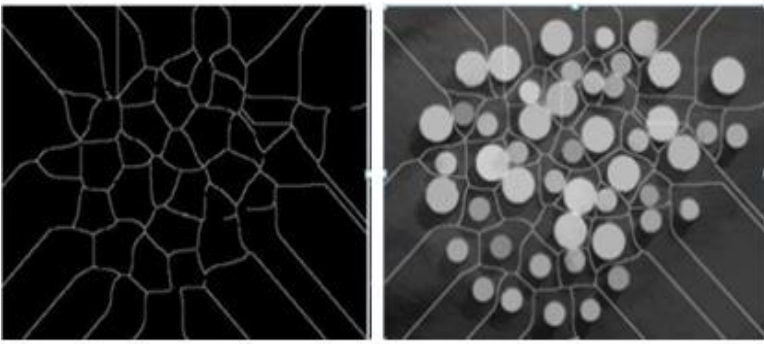

Şəkil 1

Şkil 2

Məsafə çevrilməsi üsulu ilə seqmentləşdirilmiş təsvir

Qradiyent üsulu ilə seqmentləşdirilmənin nümunəsi şəkil 3. və şəkil 4. də verilir

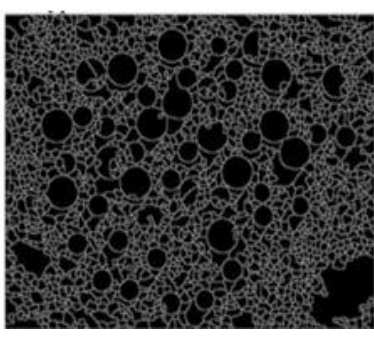

Şəkil 3.

Qradiyent üsulu ilə seqmentləșdirilmiş təsvir

Göründüyü kimi 2-ci yanaşmada həddən artıq suayırıcı xəttlər yaranıb ki bu da çatışmazlıq kimi dəyərləndirilir. Buna baxmayaraq obyektlərin konturlarının müəyyən olunması daha yaxşı olur. Şəkildəki dairəvi xəttlər obyektlərin konturlarıd1.

Qradiyent üsulunun rəqəmli təsvirlərin emalındak1 əhəmiyyətini qiymətləndirərək onun işlənilmə metodologiyasını diqqətinizə çatdırırıq.

\section{QRADİENT ÜSULU.}

Təsvirin seqmentləşdirilməsinin

aşağıdak1 xüsusiyyətləri vardır

- Təsvirdə olan müxtəlif obyektlərin pikselləri bir biri ilə üst üstə düşə bilməz $R_{i} \cap R_{j}=\varnothing, \forall i \neq j$

- Eyni obyektin pikselləri ortaq xüsusiyyətlərə malikdir $P\left(R_{i}\right)=T R U E$

- Qonşu obyektlərin fərqli xüsusiyyətləri vardır $P\left(R_{i}\right) \neq P\left(R_{j}\right), \forall R_{i}, R_{j}$ qonşudur [4].

Kənarların müəyyən olunması üçün törəmədən istifadə edərək gerçəkləşdirilən Qradiyent üsuluna baxaq.
Rəqəmli təsvirdə törəmə almaq üçün törəmənin tənliyi aşağıdakı kimi olacaq

$$
\begin{gathered}
\frac{d f}{d x}=\lim _{h \rightarrow 0} \frac{f(x+h)-f(x)}{h} \\
\lim _{h \rightarrow 0} \frac{f(x)-f(x-h)}{h}, \lim _{h \rightarrow 0} \frac{f(x)-f(x-h)}{2 h}
\end{gathered}
$$

Təsvirlər ikiölçülü olduğundan aşağıdakı Qradiyent düsturlarından istifadə ediləcək.

$$
\forall f=\operatorname{grad}(f)=\left[\begin{array}{l}
g_{x} \\
g_{y}
\end{array}\right]=\left[\begin{array}{l}
\frac{\partial f}{\partial x} \\
\frac{\partial f}{\partial y}
\end{array}\right]
$$

(Qradiyentin genişliyi düsturu)

$$
\begin{aligned}
& M(x, y)=\operatorname{mag}(\forall f)=\sqrt{g_{x}^{2}+g_{y}^{2}} \\
& \text { (Qradiyentin istiqaməti) } a(x, y)=\tan ^{-1}\left[\frac{g_{x}}{g_{y}}\right]
\end{aligned}
$$

kənarın yönü $\phi=\alpha-90^{\circ}$

Qradiyentin genişliyi praktikada aşağıdakı şəkildə hesablana bilər

$$
\begin{array}{r}
\operatorname{mag}(\forall f)=\left|\frac{\partial f}{\partial x}\right|+\left|\frac{\partial f}{\partial y}\right| \\
\operatorname{mag}(\forall f)=\max \left(\left|\frac{\partial f}{\partial x}\right|,\left|\frac{\partial f}{\partial y}\right|\right)
\end{array}
$$

Nəticədə alınan vektor, $f(x, y)$ funksiyasındakı nöqtələr üçün ən böyük artım istiqamətini əldə edir. Burada $\mathbf{x}$ və $\mathbf{y}$ piksel koordinatlarıdır.

Ogər $\left|f^{\prime}(x, y)\right|$ çox böyük nəticə verərsə, deməli $f(x, y)$ çox sürətlə dəyişir və bu o deməkdir ki, təsvirdə parlaqlıqda kəskin dəyişmişdir.

Beləliklə aydın olur ki, bir çox kənar aşkarlama alqoritminin əsasları Qradiyent amplitudunun mövcudluğuna və bir obyekt qiymətlərinin müqayisə edilməsinə əsaslanır [5].

Pikselin koordinatlarına gəlincə - hər pikselin $\mathbf{x}$ və $\mathbf{y}$ axınları boyunca bir indeksi var. Təsvirin işlənməsinin üst sol küncdə başlayacağı aydın olur. Yəni, koordinatları olan nöqtədən $(0,0)$, indeksləmə $\mathbf{x}$ oxundan sağa, $\mathbf{y}$ oxun aşağ 1 hissəsində $(0,0)$ nöqtəsindən keçir. Məsələn, təsvirin 1024x768 ölçüsü var. Təsvirin tam ortasında bir nöqtə alırıqsa, koordinatları $(512 ; 384)$ olacaq [6]. Buna əsasən biz $\mathbf{x}$ və $\mathbf{y}$ in qiymətlərini müəyyən edirik və düsturda yerinə qoyaraq təsvirin Qradiyent üsulu ilə seqmentləşdirilməsini aparırıq. Matlabda Qradiyent üsulu ilə seqmentləşdirmə aparmaq üçün bir çox funksiyalar var. $\mathrm{Bu}$ funksiyalar vasitəsilə rəqəmli təsvir üzərində müxtəlif əməliyyatlar aparıla bilər. Qarşıya qoyulan məqsəddən asılı olaraq hansı 


\section{“Informasiya tohlükasizliyinin aktual multidissiplinar elmi-praktiki problemlori” \\ IV respublika konfransl, 14 dekabr 2018-ci il}

funksiyalardan istifadə edəcəyimizi seçirik. Təsvirin seqmentləşdirilməsi prosesində qarşıya qoyulan məqsədi təmin etdiyi halda seqmentləşdirilmə dayandırıla bilər [6].

Matlabda təsvirdəki obyektlərin seçilməsi aşağıdakı kimi olacaq. İlk addımda təsvir matlab sistemində oxunur.

Seqmentləşdiriləcək olan ilkin $1838 \times 3264 \times 3$ ölçülü rəngli təsvir Şəkil 5-də verilib.

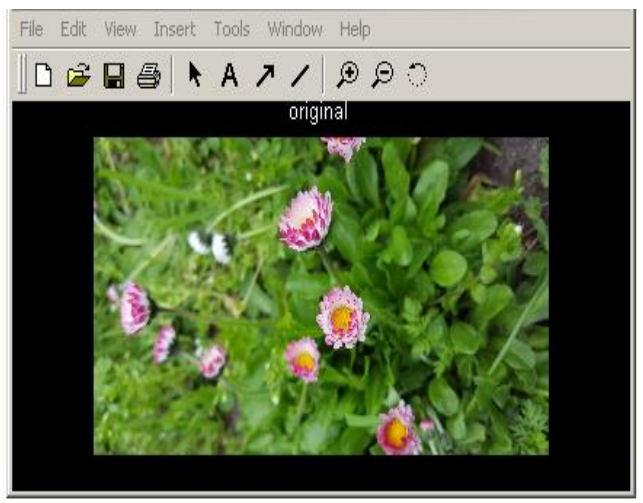

Sakil 5. İlkin tosvir

İlkin rəngli təsviri qradiyent üsulu ilə seqmentləşdirdikdə yuxarıda qeyd etdiyimiz kimi həddən artıq seqmentləşdirmə effekti nəzərə çarpır (şəkil 6).

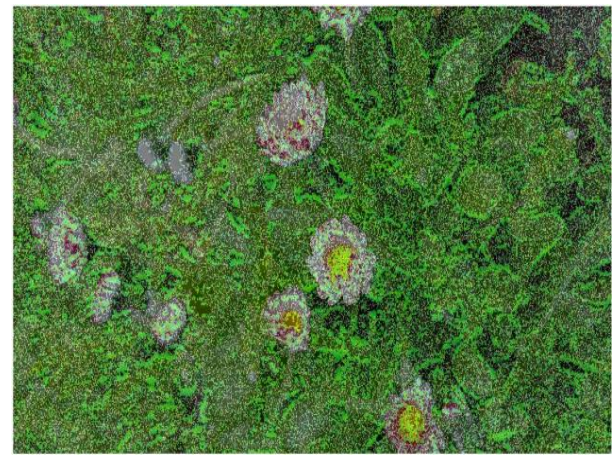

Şəkil 6. Qradiyent üsulu ilə həddən artıq seqmentləşdirilmə effekti.

Markerləşdirlmiş watershed üsulu ilə seqmentləşdirməni davam etsək fərqli nəticə alarıq. Həddən artıq seqmentləşdirilmə effekti isə aradan qaldırılır. Bunun üçün birinci növbədə Matlab da təsvir boz rəngli təsvirə çevrilir (şəkil 7).

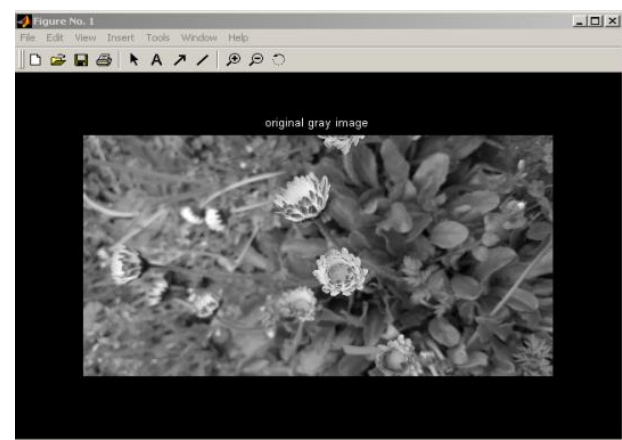

Şəkil 7. İlkin monxrom təsvir.

Daha sonra Qradiyentin qiyməti seqmentləşdirmənin funksiyası qismində istifadə edilir. Bunun üçün sobel operatoru tətbiq edilir. $\mathrm{Bu}$ addımda təsvirdəki obyektlərin kənar xətlərinin formalaşması baş verir (şəkil 8).

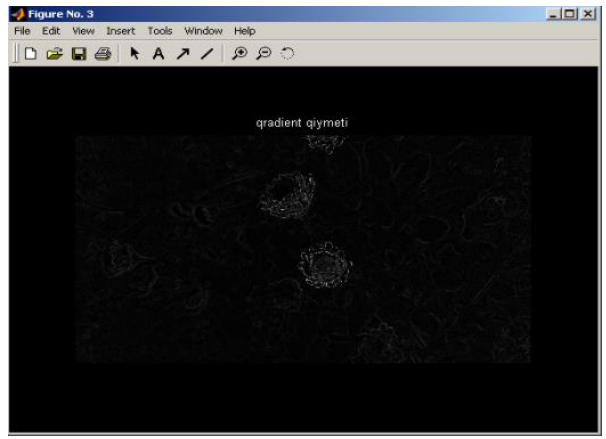

Şəkil 8. Qradiyentin qiyməti.

Beləliklə də Qradiyentin qiymətlərini hesablayaraq təsvirin seqentləşdiriməsinə keçmək olar.

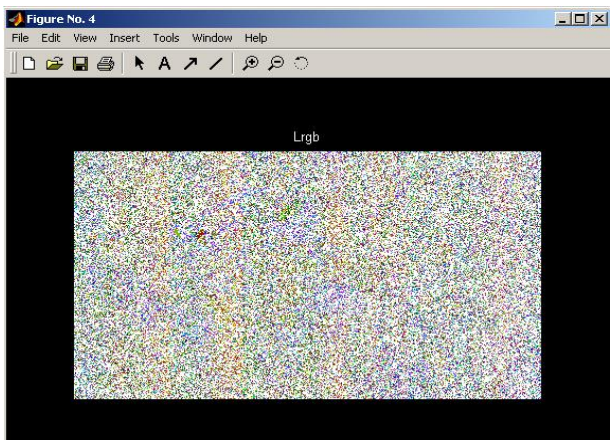

Şəkil 9. Seqmentləşdirilmiş təsvir.

Şəkil 9. də gradmag funksiyası ilə emal edilən təsvirin seqmentloşdirilmiş formasını alırıq. Lakin bu çox səthi seqmentləşdirilmə olduğundan əlavə hesablamalar tələb olunur.

Seqmentləşdirilmənin üçüncü mərhələsində təsvirdə olan obyektlərin ön planının markerlənməsi üçün müxtəlif əməliyyatlar istifadə oluna bilər. $\mathrm{Bu}$ misalda morfoloji 


\section{“Informasiya tohlükasizliyinin aktual multidissiplinar elmi-praktiki problemlori” \\ IV respublika konfransl, 14 dekabr 2018-ci il}

texnologiyalardan istifadə edərək imregionalmax funksiyası vasitəsilə təsvir analiz edilə bilər.

Lokal maksimumu hesablayaraq ön planın markerini almaq mümkündür. $\mathrm{Bu}$ onun üçün edilir ki, ön planın markerlərini ilkin təsvirin üzərinə quraşdırmaq mümkün olsun (şəkil 10).

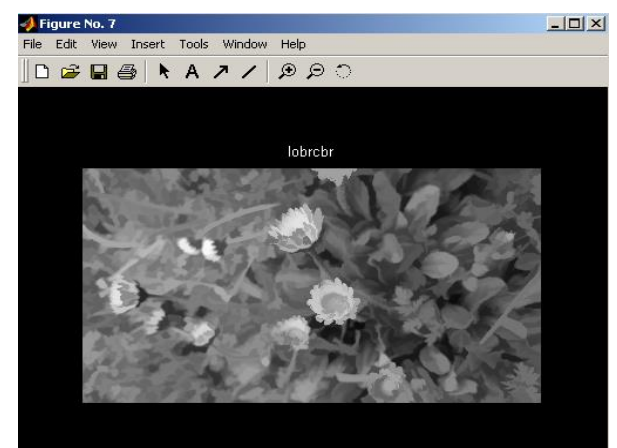

Şəkil 10. Ön plan markerləri.

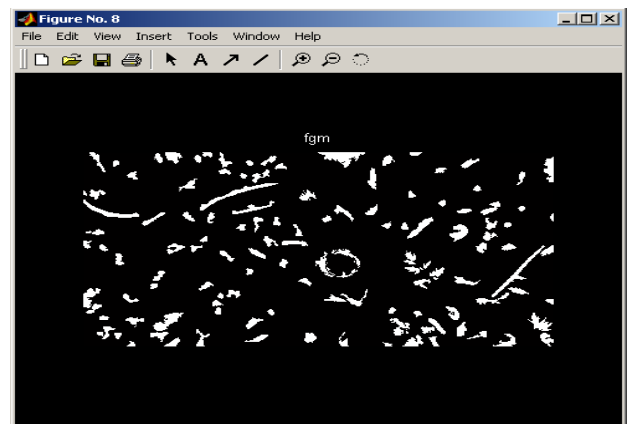

Şəkil 11. Lokal maksimumu hesablanılaraq əldə olunan ön plan markerləri.

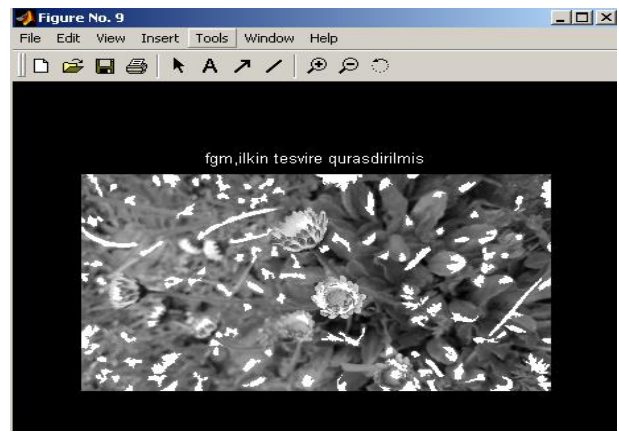

Şəkil 12. Ön planda yer alan markerlərin orijinal görüntüyə qondarılmış.

Şəkil 10 -nu şəkil 11-in üzərinə quraşdırılmasının nəticəsi şəkil 12 də göstərilmişdir.

Qeyd etmək lazımdır ki, təsvirdəki bəzi maraq doğurmayan gizlədilmiş və ya bağlanılmış obyektlər markerləşdirilməyədə bilər və seqmentləşdirmə üçün maraqlı olmadığından emal da olunmaya bilər. Bu tərzdə əldə olunan hüdudlar daha sonrakı emala məruz qalır. Belə emalın aparılması nəticəsində bir çox təsvirin izolə edilmiş pikselləri sıradan çıxır.

Təsvirin lokal minimumlarını müəyyən etmək üçün imimposemin funksiyası istifadə edilir. Həmin funksiya təsvirdəki Qradiyentləri dəqiqləşdirir və beləliklə də ön planın və arxa planın markerlərinin yerləşməsini dəqiqləşdirir və nəhayət suayırıcı üsulu əsasında seqmentləşmə əməliyyatı yerinə yetirilir (şəkil 13).

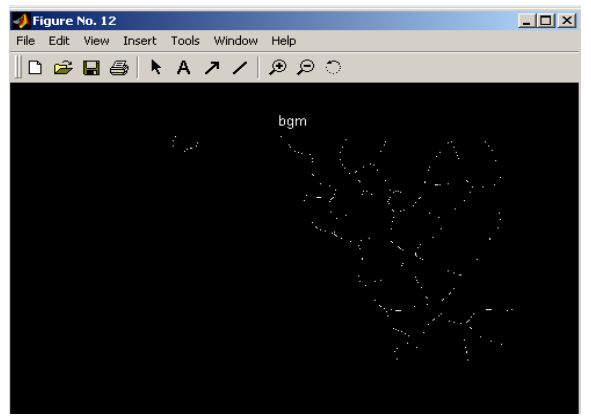

Şəkil 13. Suayırıcı xətləri

Təsvir emalının nəticələrinin vizuallaşdırılması seqmentləşdirilmənin tamamlayıcı əməliyyatlarına aiddir. $\mathrm{Bu}$ zaman nəticədə ilkin təsvirin üzərində quraşdırılmış ön planın markerləri, arxa planın markerləri və seqmentləşmiş obyektlərin hüdudları alınır (şəkil 14).

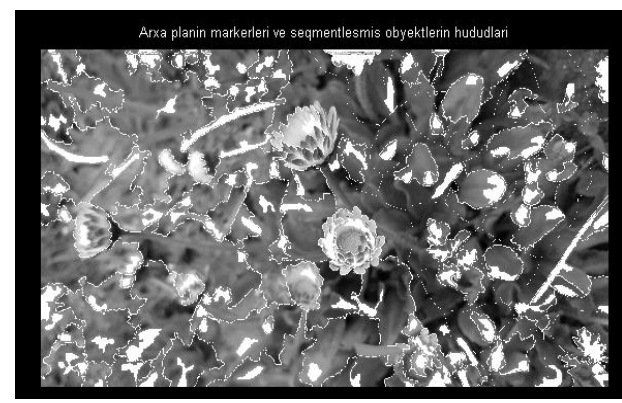

Şəkil 14. Arxa plan markerləri və seqmentləşdirilmiş obyektlərin hüdudları.

\section{NӘTİCə}

Məqalədə geniş istifadə edilən Watershed üsulunun əsas ideyası araşdırılıb və onun tətbiq edilməsi üçün mövcud yanaşmalar araşdırılıb.

Göstərilib ki, Məsafə çevrilməsi üsullarında bəzi obyektlər düzgün bölünmür və çoxlu lüzumsuz Watershed xətləri alınır

Qradient üsulunda daha çox artıq Watershed xətləri alınır, lakin bu üsulda obyektlərin konturların qurulması daha yaxşı alınır, deməli təsvirlərin təhlili və istifadəsi üçün daha yararlidir.

Hər iki yanaşmaya nisbətən işarələnmə (markerləmə) üsulu daha əlverişli görünür, çünki məsafə barədə aprior qiymətləri istifadə etmək imkanı mümkün olduğundan onları 


\section{“Informasiya tohlükasizliyinin aktual multidissiplinar elmi-praktiki problemlori” \\ IV respublika konfransl, 14 dekabr 2018-ci il}

həll zamanı effektiv istifadə etmək olur, bununla da alınan nəticə analiz üçün daha informativ olur.misalın həlli zamanı alınan nəticələr də ilkin təsvirlə müqayisədə daha aydın oxunan olur.

\section{ӘDӘBIYYAT}

[1] A. Novel "Survay on image" International Research Journal of Engineering and Technology (IRJET) 2018, vol. 5, No 6, pp. 1079-1082,

[2] Э.С. Аметова, «Подходы при сегментации изображений по водоразделам», VII Всероссийская конференция Научная инициатива иностранных студентов иаспирантов российских вузов, 2012, с.144-148. [3] Image Processing Toolbox. User's Guide. Version 5.0.1 The Math Works, 2004.

[4] A. Kızılkaya, "Sayısal görüntü üzerinde işlemler", Denizli, 2008, s. 230276.

[5] П.Г. Поля, «Математические методы обработки изображений.», Харьковский, 2013, с.82-90.

[6] Лошкарев А.С., «Сегментация изображений с помощью кластеризации», Инфокоммуникационные Технологии, Том. 15, №. 4, 2017, c.388-393.

[7] Р. Гонсалес, Р. Вудс «Цифровая обработка изображений.», М.: Texносфера, 2005, c.797-919

\section{SEGMENTATION OF DIGITAL IMAGES BY WATERSHED METHOD}

Ababil Nağıyeva ${ }^{1}$, Sakit Verdiyev $^{2}$,

Azerbaijan Technologycal University

Inagiyevaababil@gmail.com, ${ }^{2}$ info_tel@inbox.ru

Abstract - On conditions widely used image dates communication there is appeared a problem of information securing. It becomes more important to protect image dates from unauthorized users. Image treatment for effective hiding of information is a previous stage for transfer readable information to unreadable so that not any hacker or others had access to original data. Segmentation is a part of many methods for image treatment. In this paper different techniques of segmentation is considering. As a sample of segmentation technique watershed method is shown. In the same tame comparative analyse of most popular segmentation techniques, such as Spatio transformation method, Gradient and Marking method is executed and has illustrated for the colour digital images. Conclusion regarding advantages and disadvantages of every considered techniques is made.

Keywords - - digital image, segmentation, watershed, gradient, watershed marking, pixel coordinates 